\title{
Editorial
}

www.mdpi.com/journal/sustainability

\section{Sustainability in Fashion Business Operations}

\section{Tsan-Ming Choi ${ }^{1, *}$ and Yongjian $\mathrm{Li}^{2}$}

1 Business Division, Institute of Textiles and Clothing, The Hong Kong Polytechnic University, Hung Hom, Kowloon, Hong Kong, China

2 Business School, Nankai University, Tianjin 300071, China; E-Mail: liyongjian@nankai.edu.cn

* Author to whom correspondence should be addressed; E-Mail: jason.choi@polyu.edu.hk; Tel.: +852-2766-6450.

Academic Editor: Marc A. Rosen

Received: 12 November 2015 / Accepted: 12 November 2015 / Published: 19 November 2015

\begin{abstract}
Under the global trend of sustainability, many companies selling fashion products have to reshape their operational strategies. Over the past few years, we have witnessed many fashion companies going green by re-engineering their business processes and establishing their formal sustainability programs. Many important topics, such as closed-loop supply chain management, corporate social responsibility, and economic sustainability, are all related to sustainable fashion business operations management. This paper provides a brief review of these critical topics, introduces the special issue, and proposes future research areas to achieve sustainable operations management in the fashion business.
\end{abstract}

Keywords: sustainable fashion operations; sustainable supply chain management; green operations management; sustainable fashion industry; fashionable products

\section{Introduction}

Sustainability refers to the attainment of the triple bottom line (3BL), which includes environment, society, and economy [1,2]. Nowadays, sustainability is a hot topic everywhere and this global sustainability trend has led to many innovative business operations strategies in many companies selling fashion products. For instance, over the past few years, many fashion companies have gone green by re-engineering their business processes [3] and establishing their formal sustainability programs to achieve $5 R$ (reduce, reuse, recycle, re-design, re-image) [4,5]. They usually adopt a formal 
corporate social responsibility scheme and make use of it as an important tool to promote the company image [6,7]. They would employ more environmentally friendly materials (e.g., organic cotton) and conduct a lot of "eco-promotion" [8]. Fashion companies also take a more careful step in handling product returns [9] and they pay full attention to the proper management of the respective closed-loop supply chains [10-13], which include remanufacturing processes [14]. It is interesting to note that even the fast-fashion brands, which are known to be advocators of "disposable fashion", are now very "sustainable" and environmentally conscious [15]. Of course, the increase of sustainability level of fast-fashion brands is properly related to the global awareness and concerns of environmental problems as well as the strong pressure created by the consumers in the market, especially in many developed European countries [16].

In this paper, we discuss sustainability in fashion business operations in three prominent areas, namely closed-loop supply chain management, corporate social responsibility, and business strategies for sustainability. For each area, we review some related studies and also introduce the related papers published in Sustainability's Special Issue on "Sustainability in Fashion Business Operations". We also conclude by summarizing the findings and presenting the future research directions proposed in the papers of the special issue.

\section{Closed-Loop Supply Chain Management}

Closed-loop supply chain management, including reverse logistics, is a critical issue to enhance environmental sustainability. As a matter of fact, instead of moving the damaged products, scraps, and unsold fashion products to a landfill, the most important goal of closed-loop supply chain management is to properly reuse, remanufacture, and recycle all of them so that some value can be re-generated. Even though the remanufacturing process also incurs additional carbon and pollutant emissions, it is commonly believed that the remanufacturing process in closed-loop supply chain management can help reduce the damage brought to the environment. In the literature, closed-loop supply chain management has been well studied. For example, Atasu et al. [14] study the remanufacturing process as a marketing strategy. Savaskan et al. [11] and Choi et al. [12] both explore the influence of different supply chain leadership on the closed-loop supply chain's performance. For a recent review on closed-loop supply chains, refer to [13].

In this special issue, Hu et al. [17] study the rent-based closed-loop supply chain system with the goal of enhancing the level of sustainability in the fashion industry. The authors discuss many important activities in the fashion supply chain system, including fashion design and manufacturing, laundry, inventory control, and logistics, and propose some specific promotion measures for improving sustainability. Li et al. [18] conduct an evolutionary game analysis of a two-echelon closed-loop supply chain with asymmetric information. The authors propose that proper pricing and government subsidy are both critical factors to the success of remanufacturing in the closed-loop supply chain system. Wang et al. [19] investigate the optimal channel selection problem in a remanufacturing fashion supply chain. They consider the presence of a government subsidy. They find that the subsidy can provide strong support and the much-needed incentive to promote remanufacturing. At the same time, they find that if the market acceptance for the remanufactured product is high, the remanufacturer will compete with the manufacturer. They argue that the optimal choice by the remanufacturer may not 
be beneficial to social welfare and the environment. In the closed-loop supply chain, even though remanufacturing may create additional values and benefits, there is an unavoidable emission of carbon. In fact, the recent literature has extensively examined the carbon emission and pollution [20] related measures. For example, Hua et al. [21] study how companies can properly manage carbon footprints in inventory control. Choi [22] examines the local sourcing scheme for fashion companies under the quick response strategy with the consideration of the carbon footprint tax. Choi [23] investigates how the carbon taxation scheme may affect the optimal supplier selection for apparel companies. In this special issue, Oh and Jeong [24] explore this issue by building a multi-objective mixed integer linear programming optimization model to help determine the optimal product pricing, production, shipping, and stocking quantities with the considerations of both closed-loop supply chain profit and carbon emissions. Finally, He et al. [25] analyze the carbon emission abatement in fashion supply chain systems. They consider the case when there are carbon emission-sensitive consumers in the market. They examine four different scenarios in which the carbon emissions can be reduced. These four scenarios also correspond to different supply chain structures under different vertical incentives. They prove that by implementing a vertical transfer payment scheme, the carbon emissions can be reduced and supply chain profitability can be enhanced.

\section{Corporate Social Responsibility}

Nowadays, more and more fashion companies have developed formal sustainability programs and corporate social responsibility measures. In fact, the recent literature has also examined how the formal sustainability and corporate social responsibility programs affect business operations for fashion companies. For example, Caniato et al. [3] conduct an exploratory case study on the environmental sustainability in the fashion supply chain. Ho and Choi [4] investigate the 5Rs in fashion companies and they find that fashion companies have worked very hard to implement corporate social responsibility and sustainability-related schemes. In a recent study, Li et al. [5] conduct a public data empirical study on how the formal sustainability programs affect the large-scale fashion companies' ability to deal with the 2008 financial tsunami. All these studies reveal that corporate social responsibility and sustainability programs are all influential to fashion business operations.

In this special issue, Shen et al. [26] apply an analytical hierarchy process to assess the barriers of developing corporate social responsibility in textile companies. They consider the case with the fuzzy environment. They uncover the factors that are barricades to the implementation of corporate social responsibility in an Indian textile company. They find that financial constraints constitute the largest hurdle to the implementation of corporate social responsibility. Wu et al. [27] examine how the operations management practices on "lean, green, and corporate social responsibility" influence the three bottom lines for sustainability. The authors construct an integrated model and develop propositions. They argue that implementing the integrated practices together may have a more significant impact on the three bottom lines than applying the individual practices separately. In order to achieve a high standard of corporate social responsibility, fashion companies have to carefully select their suppliers and ensure the upstream supply chain is ethical and socially responsible. Timberland, a well-developed fashion brand, once got into trouble for its corporate social responsibility because it was unclear about the upstream supplier's practices of getting leathers and other materials [20]. In this 
special issue, Jia et al. [28] explore the optimal fashion supplier selection problem for getting sustainable materials supplied in fashion clothing production. The authors first identify 12 criteria from the three bottom lines' (economic, environmental, and social) perspectives for assessing suppliers. Based on a real case, they employ the multi-criteria decision making tool called "Technique for Order of Preference by Similarity to Ideal Solution" (TOPSIS) to rank the supplier candidates.

\section{Business Strategies for Sustainability}

To achieve a sustainable business operation, fashion companies have to ensure that the business is viable financially. Thus, even if the companies pay full attention to the environmental issues and social welfare [20], business profit is still critical and should never be ignored. In this special issue, Peng et al. [29] develop an analytical model to explore the project duration incentives for the fashion retailing franchising arrangement. The authors consider the over-confidence issues as well as the level of risk. They propose a new compensation mechanism which can hedge the risk when an agent breaches the franchising contract. Sheu [30] conducts a scientific study on green supply chain collaboration for fashionable consumer electronics products. Based on the resource dependence theory, the author develops a new conceptual model to explore how political and social power would affect channel power restructuring and green supply chain collaboration. Many important insights are then derived. Han et al. [31] study a single manufacturer-two retailer supply chain system in which there is price and service competition. The authors study the equilibrium prices and service levels, and reveal how the production cost and product profitability affect the equilibrium decisions and the supply chain members' economic sustainability. Finally, Shen [32] conducts a case study on a renowned fast-fashion brand, H\&M (Stockholm, Sweden), which has developed a sustainable fashion supply chain with the use of eco-materials and by following many sustainability guidelines. Based on the publicly available secondary data, the author reveals that H\&M's operations decisions may be associated with human well-being in different countries. To be specific, he finds that the sourcing team in H\&M tends to select suppliers in low-human-well-being countries and the supply chain team in H\&M may set a higher inventory level in the countries with higher human well-being.

\section{Concluding Remarks}

We have discussed in the above sections the various important areas related to sustainability in fashion business operations. Some related papers in the literature have been reviewed and the papers featured in this special issue have also been introduced. From all these discussions, there is no doubt that sustainability is a critical issue in fashion business operations and it has been examined from different perspectives, via different methods and approaches. As a summary, Table 1 presents the core issues examined by each featured paper in the special issue and the respective proposed future research directions. These proposed further studies are all constructive and important. We hope that the findings and proposed future research areas will stimulate new, cutting-edge research on sustainable fashion business operations management. 
Table 1. Core topics and future research directions of the papers featured in this special issue.

\begin{tabular}{|c|c|c|}
\hline Papers & Core Topics & Future Research Directions \\
\hline [17] & $\begin{array}{l}\text { Sustainable, rent-based, closed-loop } \\
\text { fashion supply chain management }\end{array}$ & $\begin{array}{l}\text { Conduct a real world study on the acceptance of the rent-based model. } \\
\text { Examine how consumer behaviors will affect the application of the } \\
\text { rent-based model. } \\
\text { Construct detailed optimization model for further in-depth analysis. }\end{array}$ \\
\hline [18] & $\begin{array}{l}\text { Evolutionary game analysis of } \\
\text { closed-loop supply chains under } \\
\text { information asymmetry }\end{array}$ & Extend the analysis to the case with more than two populations. \\
\hline [19] & $\begin{array}{l}\text { Optimal channel choice in a } \\
\text { remanufacturing fashion supply } \\
\text { chain with government subsidy }\end{array}$ & $\begin{array}{l}\text { Consider the channel coordination challenge with and without the } \\
\text { government subsidy scheme. }\end{array}$ \\
\hline [24] & $\begin{array}{l}\text { Profit and carbon emission analysis } \\
\text { in closed-loop fashion supply chains }\end{array}$ & Incorporate quick response and fast-fashion components into the model. \\
\hline [25] & $\begin{array}{l}\text { Analysis of carbon emission } \\
\text { abatement in fashion supply chains }\end{array}$ & $\begin{array}{l}\text { Examine the channel coordination mechanism. } \\
\text { Incorporate stochastic demand and retail pricing decision into } \\
\text { the model. }\end{array}$ \\
\hline [26] & $\begin{array}{l}\text { Evaluating barricades of corporate } \\
\text { social responsibility in the Indian } \\
\text { textile company }\end{array}$ & $\begin{array}{l}\text { Explore why the government is not much involved in corporate social } \\
\text { responsibility practices in Indian textile companies. }\end{array}$ \\
\hline [27] & $\begin{array}{l}\text { How the integrated practices affect } \\
\text { sustainability }\end{array}$ & $\begin{array}{l}\text { Collect more data to verify the framework. } \\
\text { Conduct more in-depth analysis on the three integrated practices. } \\
\text { Extend the study to focal companies and others. } \\
\text { Further explore the impacts brought by individual practices to the three } \\
\text { bottom lines. }\end{array}$ \\
\hline [28] & $\begin{array}{l}\text { Optimal fashion supplier selection } \\
\text { problem with sustainability } \\
\text { considerations }\end{array}$ & $\begin{array}{l}\text { Extend the scope to cover other functions, in addition to } \\
\text { material sourcing. } \\
\text { Consider more factors in the extended model. }\end{array}$ \\
\hline [29] & $\begin{array}{l}\text { Impacts of project duration of the } \\
\text { fashion franchising contract }\end{array}$ & $\begin{array}{l}\text { Extend the model to a more realistic setting. } \\
\text { Employ the nonlinear utility function. }\end{array}$ \\
\hline [30] & $\begin{array}{l}\text { Green supply chain collaboration } \\
\text { under the third party power } \\
\text { intervention }\end{array}$ & $\begin{array}{l}\text { Collect additional data from different industries. } \\
\text { Extend the conceptual model. } \\
\text { Consider the influence of competitor power. }\end{array}$ \\
\hline [31] & $\begin{array}{l}\text { Equilibrium analysis of supply chains } \\
\text { with price and service competition }\end{array}$ & $\begin{array}{l}\text { Use the stochastic demand. } \\
\text { Further simplify the model to generate more analytical findings. }\end{array}$ \\
\hline [32] & $\begin{array}{l}\text { A case study on sustainability } \\
\text { of } H \& M\end{array}$ & $\begin{array}{l}\text { Investigating more aspects of the sustainable fashion supply chain } \\
\text { should be considered. }\end{array}$ \\
\hline
\end{tabular}

\section{Acknowledgments}

We sincerely thank the editor-in-chief Marc A. Rosen and the managing editors Guoshui Liu and Le Zhang for their kind support for the development and completion of this meaningful special issue. We are also indebted to all reviewers and authors for their hard work. Tsan-Ming Choi's research is partially supported by the research grant PolyU 155013/14B; Yongjian Li's research is partially supported by the Major Program of the National Social Science Fund of China, Grant No. 13\&ZD147. 


\section{Author Contributions}

Both authors are guest editors of the special issue. They both have good contributions to the development and completion of this important special issue.

\section{Conflicts of Interest}

The authors declare no conflict of interest.

\section{References}

1. Drake, D.; Spinler, S. Sustainable operations management: An enduring stream or a passing fancy? Manuf. Serv. Oper. Manag. 2013, 15, 689-700.

2. Kleindorfer, P.; Singhal, K.; van Wassenhove, L.N. Sustainable operations management. Prod. Oper. Manag. 2005, 14, 482-492.

3. Caniato, F.; Caridi, M.; Crippa, L.; Moretto, A. Environmental sustainability in fashion supply chains: An exploratory case based research. Int. J. Prod. Econ. 2012, 135, 659-670.

4. Ho, H.P.Y.; Choi, T.M. A five-R analysis for sustainable fashion supply chain management in Hong Kong: A case analysis. J. Fash. Market. Manag. 2012, 16, 161-175.

5. Li, W.Y.; Choi, T.M.; Chow, P.S. Risk and benefits brought by formal sustainability programs on fashion enterprises under market disruption. Resour. Conserv. Recycl. 2014, doi:10.1016/j.resconrec.2014.08.005.

6. Choi, T.M.; Cheng, T.C.E. Sustainable Fashion Supply Chain Management; Springer: New York, NY, USA, 2015.

7. Tang, C.S.; Zhou, S. Research advances in environmentally and socially sustainable operations. Eur. J. Oper. Res. 2012, 223, 585-594.

8. Na, Y.; Na, D.K. Investigating the sustainability of the Korean textile and fashion industry. Int. J. Cloth. Sci. Technol. 2015, 27, 23-33.

9. Chaouch, B.A. A replenishment control system with uncertain returns and random opportunities for disposal. Int. J. Invent. Res. 2011, 1, 221-247.

10. Guide, V.D.R.; van Wassenhove, L.N. The evolution of closed-loop supply chain research. Oper. Res. 2009, 57, 10-18.

11. Choi, T.M.; Li, Y.; Xu, L. Channel leadership, performance and coordination in closed loop supply chains. Int. J. Prod. Econ. 2013, 146, 371-380.

12. Savaskan, R.C.; Bhattacharya, S.; van Wassenhove, L.N. Closed-loop supply chain models with product remanufacturing. Manag. Sci. 2004, 50, 239-252.

13. Souza, G.C. Closed-loop supply chains: A critical review, and future research. Decis. Sci. 2013, 44, 7-38.

14. Atasu, A.; Sarvary, M.; van Wassenhove, L.N. Remanufacturing as a marketing strategy. Manag. Sci. 2008, 54, 1731-1746.

15. Li, Y.; Zhao, X.; Shi, D.; Li, X. Governance of sustainable supply chains in the fast fashion industry. Eur. Manag. J. 2014, 32, 823-836. 
16. Choi, T.M.; Chiu, C.H.; Govindan, K.; Yue, X. Sustainable fashion supply chain management: The European scenario. Eur. Manag. J. 2014, 32, 821-822.

17. Hu, Z.H.; Li, Q.; Chen, X.J.; Wang, Y.F. Sustainable rent-based closed-loop supply chain for fashion products. Sustainability 2014, 6, 7063-7088.

18. Li, J.; Du, W.; Yang, F.; Hua, G. Evolutionary game analysis of remanufacturing closed-loop supply chain with asymmetric information. Sustainability 2014, 6, 6312-6324.

19. Wang, K.; Zhao, Y.; Cheng, Y.; Choi, T.M. Cooperation or competition? Channel choice for a remanufacturing fashion supply chain with government subsidy. Sustainability 2014, 6, 7292-7309.

20. Swartz, J. How I Did It: Timberland's CEO on Standing up to 65,000 Angry Activists. Harvard Business Review, September 2010. Available online: https://hbr.org/2010/09/how-i-did-ittimberlands-ceo-on-standing-up-to-65000-angry-activists (accessed on 31 October 2015).

21. Hua, G.; Cheng, T.C.E.; Wang, S. Managing carbon footprints in inventory management. Int. J. Prod. Econ. 2011, 132, 178-185.

22. Choi, T.M. Local sourcing and fashion quick response system: The impacts of carbon footprint tax. Transp. Res. E 2013, 55, 43-54.

23. Choi, T.M. Optimal apparel supplier selection with forecast updates under carbon emission taxation scheme. Comput. Oper. Res. 2013, 40, 2646-2655.

24. Oh, J.; Jeong, B. Profit analysis and supply chain planning model for closed-loop supply chain in fashion industry. Sustainability 2014, 6, 9027-9056.

25. He, L.; Zhao, D.; Xia, L. Game theoretic analysis of carbon emission abatement in fashion supply chains considering vertical incentives and channel structures. Sustainability 2015, 7, 4280-4309.

26. Shen, L.; Govindan, K.; Shankar, M. Evaluation of barriers of corporate social responsibility using an analytical hierarchy process under a fuzzy environment: A textile case. Sustainability 2015, 7, 3493-3514.

27. Wu, L.; Subramanian, N.; Abdulrahman, M.D.; Liu, C.; Lai, K.H.; Pawar, K.S. The impact of integrated practices of lean, green, and social management systems on firm sustainability performance: Evidence from Chinese fashion auto-parts suppliers. Sustainability 2015, 7, 3838-3858.

28. Jia, P.; Govindan, K.; Choi, T.M.; Rajendran, S. Supplier selection problems in fashion business operations with sustainability considerations. Sustainability 2015, 7, 1603-1619.

29. Peng, Y.; Zhou, J.; Wu, X. A study on project duration incentives in a retail apparel franchise. Sustainability 2015, 7, 2145-2160.

30. Sheu, J.B. Green supply chain collaboration for fashionable consumer electronics products under third-party power intervention: A resource dependence perspective. Sustainability 2014, 6, 2832-2875.

31. Han, X.; Sun, X.; Zhou, Y. The equilibrium decisions in a two-echelon supply chain under price and service competition. Sustainability 2014, 6, 4339-4354.

32. Shen, B. Sustainable fashion supply chain: Lessons from H\&M. Sustainability 2014, 6, 6236-6249.

(C) 2015 by the authors; licensee MDPI, Basel, Switzerland. This article is an open access article distributed under the terms and conditions of the Creative Commons Attribution license (http://creativecommons.org/licenses/by/4.0/). 